\title{
Grandes obras no Nordeste: 0 caso do projeto de transposição das águas do Rio São Francisco
}

Flávio José Rocha da Silva'

Resumo: Este artigo tem o seu foco no Projeto de Transposição das Águas do Rio São Francisco. $\mathrm{O}$ objeto de pesquisa está inserido no campo das grandes obras que prometem levar o "desenvolvimento" para o Nordeste brasileiro. Anunciado pela propaganda governamental como uma obra que levará água para 12 milhões de pessoas e o desenvolvimento para os estados que receberão as águas do Rio São Francisco, este projeto está reproduzindo a lógica secular das grandes obras com gastos públicos para lucros privados, além de ampliar um padrão de desenvolvimento em desacordo com a realidade dos que habitam a área de sua realização.

Palavras-Chave: Nordeste; Grandes Obras; Água; Modelo de Desenvolvimento; Comunidades Atingidas.

\section{MAGAPROJECTS IN THE NORTHEAST: THE CASE OF THE SÃO FRAN- CISCO RIVER DIVERSION PROJECT}

Abstract: This article has its focus on the São Francisco River Diversion Project. This megaproject can be classified as the biggest water project in Brazil and follows

1 Programa de pós-graduação em Ciências Sociais da Pontifícia Universidade Católica (PUC - SP) - São Paulo - Brasil - flaviojoserocha@gmail.com 
other megaprojects that promised to "develop" the Northeast of Brazil. The São Francisco River Diversion Project, publicized by the government as a Project that will provide water for more than 12 million people, reproduces the historical way to deal with the problems in the Northeast by affirming a model of development that degrades the environment and does not respect the reality of those who live in the area where is located.

Key-Words: Northeast of Brazil; Megaprojects; Water; Model of Development; Impacted Communities.

\section{Introduç̃̃o}

O Projeto de Transposição das Águas do Rio São Francisco - PTARSF - é apresentado pelo governo como a solução para a insegurança hídrica no semiárido nordestino e uma nova alavanca para o desenvolvimento do Nordeste (NE). Transposição de águas de rios para grandes distâncias estão registradas na história desde 0 ano 312 a.C., com a construção de aquedutos pelos romanos (Rebouças, 2002). No Brasil, também não é algo recente. ${ }^{2} \mathrm{O}$ que faz a diferença no caso do PTARSF é que de forma surpreendente existem grupos organizados na sociedade civil e no âmbito acadêmico/científico questionando a real necessidade de mais esta grande obra em uma região que ficou marcada no imaginário brasileiro como deficitária em recursos hídricos.

Inicialmente chamado de Projeto de Transposição do Rio São Francisco, esta obra passou a ser chamada de Projeto de Integração das Bacias do Rio São Francisco no auge do embate entre os grupos organizados contrários ao projeto e o governo federal. Mais tarde, foi rebatizado de Projeto de Integração do São Francisco - PISF - em uma tentativa do governo de reverter a má imagem do projeto junto à opinião pública. Atualmente, é chamado de Projeto Rio São Francisco, dando continuidade à tradição de rebatizar os projetos para aquela região do Brasil. O novo batismo não conseguiu fazer com que o primeiro nome dado ao projeto fosse esquecido e ele continua conhecido popularmente como Transposição do Rio São Francisco. O PTARSF foi uma das obras incluídas no Programa de Aceleração do Crescimento - PAC - e, segundo Loureiro, Teixeira e Ferreira (2014: 12), “[...] ele estará isento de quaisquer contingenciamentos orçamentários e que se beneficiará do Regime Diferenciado de Contratações de

2 Os estados de São Paulo e Rio de Janeiro realizaram os primeiros projetos de transposição de bacias no Brasil para levar água para suas capitais ainda nos anos 1950. Para conhecer algumas experiências de transposição de águas no Brasil e no mundo, confira Azevedo (2012). 
Obras Públicas (RDC), que permite redução de exigências na Lei de Licitação Pública (Lei 8.688)."

A primeira vez que se cogitou transpor as águas do Rio São Francisco para uma outra área do Nordeste foi em 1820. De acordo com afirmações de Bezerra (2002: 99),

Em meados do século XIX, o dr. Marcos Antônio de Macedo tratou da transposição do Rio São Francisco para o Ceará. Ele referia-se à viabilidade do empreendimento empregando a terminologia da época, falando de "canalização". Comentou que um padre carmelita de nome João de Santa Rosa, já por volta de 1820, no Crato, falava na possibilidade dum canal de transposição. Refere a história que aquele religioso elaborou um documento nesse sentido e enviou-o a D. João VI, rei do Reino Unido de Portugal, Algarve e Brasil. Este, às vésperas de deixar o Brasil (abril de 1821), teria recomendado a construção da obra a seu filho, o Imperador D. Pedro I, que ordenou ao sr. Costa Barros, presidente da Província do Ceará, que diligenciasse no sentido de verificar a "possibilidade e vantagens de tal empreendimento". Os estudos nesse sentido caíram no esquecimento por causa dos episódios que marcaram a Confederação do Equador, em 1824, movimento separatista ocorrido em várias províncias nordestinas.

Mais tarde, essa proposta sempre voltaria à tona durante as estiagens prolongadas ou durante as eleições presidenciais como uma tentativa de angariar votos. A cada seca exacerbada por uma crise econômica com reverberações políticas, a obra saía das gavetas governamentais como um remédio anunciado com total eficácia para uma doença na qual abundam diagnósticos como o resultado certeiro para matar os sintomas indesejados. Isso aconteceu, por exemplo, em 1959, quando depois da seca do ano anterior e uma derrota eleitoral, o Presidente Juscelino Kubitscheck ordenou que o DNOCS fizesse estudos sobre a viabilidade da transposição. Em 1996, o Conselho de Desenvolvimento do Vale do São Francisco e do Parnaíba - CODEVASF - divulgou um estudo intitulado Projeto semi-árido: proposta de desenvolvimento sustentável da bacia do rio São Francisco (Brasil, 1996: 31), no qual já propunha uma rede de "[...] aproximadamente $3.700 \mathrm{~km}$ de canais e reservatórios interligados, abastecidos a partir do Rio São Francisco nos três reservatórios existentes - Sobradinho, Itaparica e Xingó - e na cidade de Cabrobó-PE, permitindo atender aos Estados do Piauí, Pernambuco, Bahia, Sergipe, Alagoas, Paraíba, Rio Grande do Norte e Ceará." Peça publicitária até 2004, o PTARSF tornou-se real na forma de dois grandes canais de concreto a rasgarem a região semiárida brasileira a partir do ano de 2005. 
Era de se esperar que com o sucesso dos novos modelos de convivência com o semiárido, que convergem para uma redefinição de como se servir do patrimônio hídrico a ser utilizado pelos moradores daquela área para a produção e o uso doméstico, não ressurgissem grandiosos projetos, como o PTARSF, com a eterna promessa de que este resolverá todos os problemas daquela região. No entanto, o tema da transposição das águas do Rio São Francisco voltou à mídia quando o então Ministro da Integração Nacional, Ciro Gomes, anunciou em 2004 que o PTARSF era uma prioridade para o governo do Presidente Luiz Inácio Lula da Silva. ${ }^{3}$

Nesse sentido, este artigo tem o objetivo de refletir sobre como esse projeto está inserido na lista de grandes obras no Nordeste que prometem o desenvolvimento para aquela região, mas proporcionará água principalmente para o agronegócio da fruticultura irrigada. Para fundamentar tal afirmação, nos alicerçamos em referências bibliográficas de vários autores estudiosos do tema e do Relatório de Estudo do Impacto Ambiental - Rima - do PTARSF.

\section{Explicando o PTARSF}

Sendo a maior obra hídrica já planejada e em execução no Brasil, a estrutura do PTARSF é gigantesca. $O$ projeto prevê a construção de dois canais chamados de Canal do Eixo Norte e Canal do Eixo Leste, ambos somando mais de setecentos quilômetros, para levar as águas do Rio São Francisco para o Nordeste Setentrional, nos estados de Pernambuco, Rio Grande do Norte, Paraíba e Ceará.

Entretanto, Fontes (2010: 233) adverte que não podemos falar de apenas uma transposição, pois

É necessário esclarecer que apesar de ser tratado como um projeto único, na realidade tratam-se de duas transposições: o eixo Leste e o eixo Norte. É um erro grave dar um tratamento conjunto aos dois eixos, vez que a situação hídrica da região onde se destinam é totalmente distinta. Da mesma forma que a destinação das águas, a vazão e o custo de cada eixo são completamente diferentes.

3 O ex-presidente Lula era contra o PTARSF até chegar ao poder, como pode ser atestado pelo áudio presente na abertura do documentário Ser tão progresso (Cancino, 2012). De forma coincidente, o PTARSF ganha vulto durante o famoso escândalo conhecido como Mensalão, que envolveu o seu governo em 2005. Escobar (2009: 262), ao discorrer sobre alguns governos pretensamente do campo da esquerda na América Latina, afirma que "Em su afan por superar el modelo neoliberal los gobiernos progressitas há revitalizado el desarrollismo a nombre del cambio radical." - "Em seu afã de superar o modelo neoliberal, os governos progressistas hão revitalizado o desenvolvimentismo em nome da mudança radical." (Tradução do autor). 
As águas desses canais desembocarão em oito açudes do Nordeste e, segundo Ribeiro (2010), irão perenizar os rios Salgado (6o km), Jaguaribe $(80 \mathrm{~km})$, Apodi (9o km), Piranhas Açu (130 km) e Paraíba (150 km). Sua distribuição também acontecerá de forma que o Eixo Norte receberá mais água do que o Eixo Leste. Ou seja, o Ceará, um dos estados receptores do Eixo Norte e que já possui grande reserva hídrica, será o maior beneficiado. $\mathrm{O}$ traçado dos canais tem uma clara influência de interesses econômicos, privilegiando as áreas de alguns vales do semiárido para favorecer a irrigação de grandes plantações. Estes fatos demonstram um contrassenso na justificativa do projeto, já que, segundo os seus defensores, a transposição levará água onde esta é uma real necessidade.

A obra foi prometida pelo Presidente Lula a um custo de 4,5 bilhões de reais em 2005, passou para 6,6 bilhões em 2010, e atualmente já foram gastos mais de 10 bilhões de Reais. Quanto custará a sua conclusão, ainda não se sabe, ${ }^{4}$ mas alguns estudiosos do tema afirmam que ela pode chegar a um custo de 20 bilhões de reais. Assim como ocorreu com o orçamento, a promessa para a sua conclusão também foi modificada. Primeiramente, foi prometida pelo Presidente Lula para 2010. Depois, foi anunciada pela Presidenta Dilma para 2012. Por fim, o Presidente Michel Temer inaugurou o Eixo Leste em março de 2017. Quanto ao Eixo Norte, este continua em obras. No entanto, o próprio Relatório de Impacto Ambiental - Rima - previu que o PTARSF somente estaria em plena operação de quinze a vinte anos depois do início das obras (Brasil, 2004: 51).

É preciso que seja ressaltado que uma das razões ocultadas para a realização do PTARSF é o fato de que o semiárido não tem variações climáticas contrastantes como outras regiões do país (geadas, por exemplo). O que parecia ser sua condenação com o sol a banhá-lo por cerca de trezentos dias por ano, é um grande atrativo para a produção de frutas tropicais. Aquela região é vista atualmente como a nova fronteira agrícola brasileira depois do cerrado. É uma área sem grandes variações de temperatura, com uma topografia de vales extensos, mão de obra barata, aproximação geográfica com a Europa e os Estados Unidos, os portos de Suape, em Pernambuco, e de Pecém, no Ceará, além da futura Ferrovia Transnordestina que servirá para o escoamento da produção do agronegócio. Há uma necessidade de garantia da água para a irrigação, dada a imprevisibilidade das chuvas naquela região e, por isso, não se pode comprometer

4 Sobre o gasto com o PTARSF, disse Celso Furtado (Tavares; Andrade; Pereira, 1998: 44): "Eu não me interessei por este projeto desde o começo porque era uma panaceia. Minha reação imediata foi de cautela. Sempre perguntei: a quanto chega o investimento? Nunca ninguém conseguiu me dizer quanto custaria. Em segundo lugar, quem vai ser beneficiado com isso? São os proprietários de terras? Então terão novos açudes para evaporar? Portanto, o problema não está em ter mais água, mas em usar bem a água que já existe." 
os reservatórios com a irrigação. Nascimento e Cagnin (2010: 78) afirmam que "A necessidade de maior garantia é uma tendência da economia atual, exigente de segurança de suprimento dos fornecedores para viabilizar parcerias comerciais e vendas. Sem garantia, o setor privado vai procurar outras áreas onde investir, inibindo o desenvolvimento regional.” A realização do PTARSF é a garantia de que não faltará recursos hídricos para a irrigação em caso de uma grande estiagem. ${ }^{5}$ A sua finalização fará o semiárido torna-se o lugar perfeito para a expansão da fruticultura irrigada, como já aconteceu em outras áreas semiáridas do mundo, a exemplo da Califórnia, África do Sul e Israel. ${ }^{6}$ A quantidade de aproximadamente 300 dias de insolação, o que sempre pareceu um grande fator negativo no passado, é na verdade um grande benefício para o agronegócio, que, ajudado pelo governo na infraestrutura, pode lucrar com até três colheitas anuais, a depender da cultura plantada. Castro (2011: 32) revela que "O MI estima que haverá até 2025 uma expansão da área irrigada nas bacias beneficiadas pela transposição de aproximadamente 190 mil hectares."

Defensores do PTARSF afirmam que o projeto promoverá a sinergia hídrica no Nordeste Setentrional, o que beneficiará os mananciais que atendem às populações da região, acabando com a escassez hídrica. ${ }^{7} \mathrm{O}$ que muitos ainda não sabem é que o PTARSF é apenas "o grande iceberg visível no mar." Por trás dos dois canais principais, há uma série de pequenos e médios canais que receberão as águas do Velho Chico para projetos de irrigação e até para a siderurgia. Baseado em Maranhão e Ayrimoraes (2012), citaremos alguns deles:

5 Atente-se para o fato de que o autor Pedro Brito Nascimento foi o Coordenador Técnico do PTARSF em 2005 e Ministro da Integração Nacional entre 2006-2007. O outro autor, João Urbano Cagnin, foi o Coordenador Técnico do PTARSF entre 1997-2005.

6 Para Ribeiro (2008: 41), "A fruticultura exportadora praticada no Nordeste brasileiro é um exemplo de emprego insustentável dos recursos hídricos. Frutas exóticas foram introduzidas em meio ao sertão, onde se encontra baixa pluviosidade e elevada insolação, sob alegação de que podem ser vendidas no mercado externo a preços mais competitivos devido às distâncias menores da Europa e dos EUA se comparadas às tradicionais regiões produtoras destas frutas no Brasil."

7 Como afirma Siqueira (2005: 40), "No contexto do discurso ideológico, a escassez, posta de maneira genérica e abstrata como risco global e iminente, induz à aceitação de um elenco de propostas gerais visando tornar eficiente a gestão da água, bem como racionalizar seu uso. De maneira mais ou menos sutil, introduz-se, como consequência lógica, a justificação da mercantilização da água, na medida em que a escassez lhe agrega, necessariamente, valor econômico." Ressaltamos que há uma certa confusão entre os termos estresse hídrico e escassez. "O estresse hídrico é a pressão exercida pela falta de água enquanto a escassez representa a efetiva falta de água." (Ribeiro, 2008: 71). O programa das Nações Unidas para o Meio Ambiente "[...] define escassez hídrica quando a população de uma determinada região dispõe de menos de $1.000 \mathrm{~m}^{3}$ de água por ano nas reservas naturais (rios, lagos e águas subterrâneas). (Ribeiro, 2008: 63). O mesmo programa "[...] definiu um valor mínimo para estresse hídrico em sua página eletrônica: menos de $1.700 \mathrm{~m}^{3}$ per capita ao ano." (Ribeiro, 2008: 64). 
1. Sistema Adutor do Agreste, em Pernambuco, composto por canais e aquedutos;

2. Canal do Sertão Alagoano, em Alagoas, contemplará 26 perímetros de irrigação;

3. Canal do Xingó, em Sergipe;

4. Canal do Sertão Pernambucano;

5. Canal Terra Nova, em Pernambuco;

6. Canal Arco-Î́ris, em Pernambuco;

7. Canal da Vertente Litorânea, na Paraíba, com projeção para irrigar 10 mil ha;

8. Cinturão da Águas, no estado do Ceará;

9. Eixo de Integração do Seridó, no Rio Grande do Norte.

Teme-se que seja repetido o que já aconteceu com outros canais que prometiam a garantia do abastecimento de água para a população e hoje apenas fornecem água de boa qualidade para a irrigação da agricultura em grande escala para a exportação. Casos como o dos canais construídos no Ceará, ${ }^{8}$ prometidos pelo então governador cearense Ciro Gomes, no ano de 1993, como a solução para o abastecimento de água da capital cearense Fortaleza e depois apropriados por grandes conglomerados econômicos que produzem e exportam frutas, demostram o que pode acontecer com PTARSF no futuro. ${ }^{9}$

\section{A privatização da água e o PTARSF}

Uma das grandes controvérsias sobre o PTARSF é o fato de que ele fortificará o mercado da água no Brasil com a cobrança da água transposta, algo que já vem acontecendo em várias bacias hidrográficas brasileiras. Além disso, o PTARSF terá 70\% de suas águas destinadas à irrigação de grandes projetos de agricultura em larga escala para exportação e para a carcinicultura, o que poderá gerar inúmeros conflitos pela sua utilização. Não que as águas do Velho Chico já não estejam envolvidas em conflitos diversos, mas o PTARSF desvelou para o país que, mesmo onde há água em abundância, a chegada do agronegócio, agora chamado por alguns de agrohidronegócio, acelera esse processo conflituoso.

8 Em 1993, com o argumento de que faltaria água em Fortaleza, o então governador Ciro Gomes contratou 12 empreiteiras para a construção de mais de $100 \mathrm{~km}$ de canal (Martins, 1993). No total, este canal terá 225 quilômetros e, segundo Alcântara (2006: 297), "Ao final do seu percurso, o Canal da Integração terá passado por doze municípios, irrigando pelo menos 33 mil hectares e garantindo água para o Complexo Industrial do Pecém e os distritos industriais de Maracanaú, Horizonte e Pacajus."

9 Confira o documentário Transposição do Rio São Francisco e águas no Ceará: os cursos da privatização (Frente cearense por uma nova cultura de água e contra a transposição, 2007). Disponível em: $<$ https://www.youtube.com/watch?v=fu7z7Dwbzk8>. Acesso em: 12 nov. 2018. 
Está sendo instituída a "indústria da água" como uma sucedânea da indústria da seca. Algo que foi planejado pelo governo do Presidente Fernando Collor de Melo e foi acelerado pelo governo do Presidente Fernando Henrique Cardoso quando foi criado o programa Proágua semiárido que, de acordo com Martins (2012: 475),

Financiado pelo próprio Banco Mundial, o Programa tinha como objetivo construir estratégias de gerenciamento das disponibilidades e as demandas de água na região semiárida brasileira, considerando não apenas a bacia hidrográfica e os múltiplos usos da água, mas também analisando seu valor econômico ante o potencial de escassez e as demandas dos usuários.

A Indústria da Água, ou hidronegócio, como última fronteira a ser desbravada pelo capitalismo é uma realidade vivenciada por várias populações em todo o mundo. ${ }^{10}$ É nesse sentido que a realização do PTARSF se encaixa perfeitamente no processo de mercantilização da água. Quanto custará a água transposta e quem por ela pagará? Críticos do PTARSF falam que esta será a água mais cara do país e impossibilitará que pequenos agricultores tenham acesso a ela em suas pequenas propriedades. Além disso, a produção de frutas e de camarão para a exportação é o que os estudiosos da questão hídrica chamam de exportação de água virtual. ${ }^{11}$ Ao exportar estes produtos, o NE está exportando água. Uma ironia, se atentarmos para o fato de que durante décadas este é um lugar conhecido pela necessidade de construção de megaprojetos justificados pela escassez hídrica.

Em princípio, o PTARSF será administrado pelo governo em conjunto com os estados receptores. Porém, existem casos como o do Projeto Especial Chavimochic, no Peru (Azevedo, 2012), em que o canal foi administrado inicialmente pelo governo e depois passou para a iniciativa privada. ${ }^{12}$ No Brasil, isto pode acontecer por meio das Parcerias Público-Privadas ${ }^{13}$ - PPPs. No fim, corre-se o risco de se repetir o modelo de tonar as despesas públicas enquanto os lucros serão privados.

10 Confira El Convenio Azul; la crisis global del agua y la batalla futura por el direch al agua (Barlow, 2008).

11 Há várias bases de cálculo para se chegar aos resultados da chamada exportação da água virtual. Uma delas é a Waterfootprint. Confira em: <http://www.waterfootprint.org/>. Acesso em: 12 nov. 2018. "Desde agosto de 2003, Chavimochic é administrado por um órgão executivo desvinculado do governo regional de La Libertad e conta com autonomia técnica, econômica, financeira e administrativa. Tem participação de investidores privados que ocupam uma área total de 26.893 ha irrigados, dos quais 8.500 ha se encontram em produção para cultivos para exportação." (Azevedo, 2012: 348).

13 Sobre a Parceria Público-Privada - PPP - relacionada aos recursos hídricos, afirma Petrella (2002: 33): "A parceria público/privado com relação à água tende a cultivar e a implementar as visões e abordagens do setor privado de forma que a água (a fonte da vida) está em perigo de tornar-se gradualmente uma das principais fontes de lucro, uma das últimas áreas a serem conquistadas para a acumulação privada do capital." 


\section{Razões para ser contra, razões para ser a favor ao PTARSF}

$\mathrm{O}$ conflito socioambiental relacionado à água que mais ganhou destaque no Brasil nos últimos anos foi o PTARSF. A tensão gerada por esta obra mostrou ao país que a realidade do Nordeste é plural e que, apesar de aquela região possuir mais de 70 mil açudes com um estoque de água da ordem de 37 bilhões de metros cúbicos (Suassuna, 2007), há populações ainda excluídas do acesso a este bem essencial para a sobrevivência de forma qualitativa, mesmo aquelas que vivem próximas ao Rio São Francisco. Além disso, há uma grande preocupação por parte dos que habitam as margens do Velho Chico com as consequências da tomada de água de um manancial já debilitado.

Afinal, a quem pertencem as águas do Rio São Francisco? O que e quem deve delas se servir? Estas são questões que também vêm à tona por parte de alguns opositores e defensores da transposição do Velho Chico. Como corta vários estados, por lei ele tem caráter federal. Um dos impasses acontece porque os estados de Minas Gerais e Bahia argumentam que quase $80 \%$ das águas daquele manancial vem desses estados. Com uma possível crise hídrica na bacia, não é justo, segundo alguns críticos do PTARSF nesses estados, que as águas do Velho Chico sejam transpostas para centenas de quilômetros e desabasteça os mineiros e baianos. Defensores respondem que a maior parte da poluição deste manancial também acontece nesses estados.

Segundo Said (2009: 27), a Lei n. 9.433/97, que cria os comitês de bacias, estabeleceu três critérios principais para transposição de águas que não são atendidos pelo PTARSF. São eles:

1- Uma das bacias ou uma área com terras irrigáveis, mas sem ou com pouca água para irrigações: a bacia receptora.

2- Outra bacia com muita água sobrando, mas sem terras próprias para irrigação: a bacia doadora;

3- Que a transposição possa ser feita economicamente (por gravidades ou pequena altura de elevação, com transporte a menores distâncias).

Estudiosos apontam alguns impactos tanto na bacia doadora quanto nas bacias receptoras do PTARSF. Ab'Saber (2008: 32), por exemplo, afirma que "Os vazanteiros que fazem horticultura no leito dos rios que cortam - que perdem o fluxo durante o ano - serão os primeiros a ser totalmente prejudicados." Eles cultivam o leito do rio por cinco ou seis meses por ano e produzem hortaliças que são vendidas nas feiras livres do sertão nordestino. Ab’Saber (2006) também levanta a questão das águas poluídas pelos esgotos jogados no São Francisco e que se juntarão às águas salinizadas dos grandes açudes do semiárido que receberão 
as águas transpostas e que serão consumidas pelas populações urbanas do Nordeste Setentrional. A questão da energia hidrelétrica produzida pelas usinas construídas no Velho Chico e que fornecem $95 \%$ da eletricidade consumida naquela região também tem sido um tema repetido à exaustão por Suassuna (2000; 2007; 2010; 2012). Já Said (2009) afirma que, na região de Cabrobó-PE, a construção da barragem de Areias deslocará 54 famílias que lá vivem da pesca no Rio São Francisco há mais de dezenove anos. Para Guimarães Jr. (2007: 109), "O Projeto deverá agravar os conflitos pelo uso da vazão na bacia do Rio São Francisco, tendo em vista que, na época de aprovação do projeto, praticamente toda a água da bacia já se encontrava comprometida." Este mesmo autor (Guimarães Jr., 2007) também enfatiza que o projeto não leva em conta o grande potencial das águas subterrâneas e as vazões do semiárido. Acrescente-se a esta lista o desmatamento da caatinga e $o$ isolamento de espécies nativas de animais que ficarão separadas pelo canal, assim como comunidades que terão a sua locomoção dificultada pelo projeto. Barbosa e Lima Filho (2010: 50) argumentam que "A interligação de bacias proporcionada pela transposição trará evidentes mudanças significativas na biodiversidade local. A continuidade do curso da água ligará áreas que sazonalmente eram separadas, promovendo a junção de biotas, e por outro lado irá separar áreas que anteriormente tinham um fluxo livre em determinadas épocas do ano."

Grupos contrários ao PTARSF alegam que $70 \%$ da água transposta servirá aos projetos de irrigação de fruticultura, para a siderurgia (já que o Eixo Norte servirá para garantir água para o Distrito Industrial de Pecém-CE $)^{14} \mathrm{e}$ para a carcinicultura, não se destinando apenas para o consumo humano e animal, como propagado pelo governo. Além disso, estes mesmos grupos alegam que não houve uma discussão com a sociedade civil, principalmente com os grupos atingidos, como os indígenas e os quilombolas, e que, por tratar-se de um projeto que custará bilhões de reais aos cofres governamentais, merecia ser melhor discutido. ${ }^{15}$ Também preocupa a estes grupos o valor que será cobrado pela água

14 "Para viabilizar os outros empreendimentos, o governo dotou o Pecém da infraestrutura necessária à implantação de um distrito industrial, com o objetivo de trazer grandes empresas para o estado que já dispunha de energia e estradas, mas faltava água. Daí, foi construído o Castanhão para armazenar a água; iniciou-se o Canal da Integração que levaria água do Castanhão para Fortaleza e para o distrito industrial. Essa era a justificativa da transposição para o desenvolvimento do Ceará. Naquela gestão, esse plano não se concretizou, mas 22 anos depois, o plano começa a se concretizar e a sua garantia é a transposição das águas do São Francisco. Em suma, só haverá siderúrgica, refinaria e agora, termoelétricas, se houver transposição." (Said, 2009: 47).

15 Para Ab'Saber (2006: 13), “Convém lembrar que, um projeto democrático, inteligente e bem elaborado, nunca se poderá dizer autoritariamente que 'se trata de um projeto político do presidente', mesmo porque todo projeto exclusivamente político é, por princípio, uma autoafirmação sobre o seu caráter demagógico eleitoreiro." 
transposta, pois, segundo Said (2009), haverá um subsídio cruzado fazendo com que as populações urbanas paguem por $85 \%$ da manutenção do PTARSF. ${ }^{16}$ Outro aspecto contestado do projeto é a afirmação do governo de que apenas $1 \%$ da água do rio será transposta, o que não é uma garantia (Coelho, 2005).

Segundo Barbosa e Lima Filho (2010: 49), "A enorme carência dos estudos que forneçam informações sobre os impactos decorrentes desta interligação persiste às décadas de debates e discussão sobre a viabilidade do empreendimento, principalmente no âmbito dos inevitáveis impactos ambientais." Há muitas críticas sobre o Rima, sobretudo de que este não abarcou toda a bacia do São Francisco, enfocando apenas a área de construção dos canais. Além disso, a "[...] carência de estudos que forneçam informações sobre os impactos decorrentes da integração das bacias da região, tornam a realidade do projeto de transposição impactante do ponto de vista ambiental, social e econômico." (Barbosa; Lima Filho, 2010: 49).

Khoury (2007) ressalta que a Constituição Federal foi violada porque a captação do Eixo Norte localiza-se em Terra Indígena Truká, e várias normas do Estudo de Impacto Ambiental desconsideram os impactos negativos. Ainda de acordo com Khoury e Marques (2008: 206),

Dentre as violações constitucionais, tem-se a do artigo 49 da Carta Magna Brasileira. Este artigo da Constituição Federal de 1988 estabelece que é competência exclusiva do Congresso Nacional aprovar o aproveitamento dos recursos naturais em terras indígenas. $O$ ponto de captação de água do Eixo Norte, em Cabrobó/PE, fica a oitenta metros da ilha de Assunção, território do Povo Truká, já demarcado. Outros pontos da obra cortam terras dos povos Truká e Pipipan.

Outra questão apontada é que apenas $5 \%$ da água irá para a população difusa e esta já tem soluções mais baratas para a sua dessedentação, como as apresentadas pelos Projetos de Convivência com o Semiárido. ${ }^{17}$ É verdade que cidades como Campina Grande-PB e Caruaru-PE, por exemplo, têm problemas com o abastecimento de água para suas populações. É preciso levar em conta que, no caso de Campina Grande, o açude Epitácio Pessoa foi construído na década de 1950 e desde então vem sendo assoreado, além de ter as suas águas utilizadas

16 Segundo afirmação de Feijó e Torggler (2007: 135), "Ainda que cobrados os R\$ 0,11 por $\mathrm{m}^{3}$ do consumidor final, o subsídio ainda será da ordem de US\$ 0,22 por metro 3 , ou seja, 83\% do custo real. O custo 'oficial' é baixo porque, nos cálculos daqueles técnicos, há erro na estatística de vazão, bem como omissão da depreciação e dos juros."

Para conhecer alguns destes projetos, confira Silva (2008). 
para a irrigação de plantações no seu entorno. Além disso, o Rio Paraíba, que o abastece, sofreu vários barramentos antes de desaguar no açude e sofre com ações que degradam aquele manancial.

Os defensores do PTARSF garantem que ele levará água para 12 milhões de pessoas, mas os números da propaganda ${ }^{18}$ governamental não esclarecem que esta é a projeção para quando o projeto estiver concluído e que aí estão computadas as populações urbanas das grandes cidades do Nordeste Setentrional.

Outro argumento a favor do PTARSF é que, segundo Sarmento (2006: 16),

O Estado brasileiro tenta desenvolver o Nordeste sob os paradigmas da globalização, centrando atenção nos setores que melhor respondem à alocação de investimentos condicionados ao dinamismo competitivo mundial, como a fruticultura irrigada, o turismo e a indústria têxtil, está em franco soerguimento.

O Relatório de Impacto Ambiental do PTARSF apontou quarenta e quatro impactos, sendo que, destes, apenas doze são positivos. Com base em alguns autores e no Rima (Brasil, 2004), transcrevemos alguns a seguir:

Quadro 1 - Governo e movimentos sociais disputam argumentos contra e a favor do PTARSF

\begin{tabular}{|l|l|}
\hline ARGUMENTOS A FAVOR & ARGUMENTOS CONTRA \\
\hline $\begin{array}{l}\text { Prevenir o desabastecimento dos centros } \\
\text { urbanos. (Brasil, 2004) }\end{array}$ & $\begin{array}{l}\text { Levará água para os grandes açudes, onde já } \\
\text { há muita água armazenada. (Feijó; Toggler, } \\
\text { 2007: 137) }\end{array}$ \\
\hline $\begin{array}{l}\text { A água transposta atenderá 12 milhões de } \\
\text { pessoas. (Brasil, 2004: 3) }\end{array}$ & $\begin{array}{l}\text { Quando a vazão for de 63 } \mathrm{m}^{3}, 70 \% \text { da água } \\
\text { será para a irrigação. (Feijó; Toggler, 2007: 137) }\end{array}$ \\
\hline $\begin{array}{l}\text { Visa suprir usos múltiplos. (Nascimento; } \\
\text { Cagnin, 2010) }\end{array}$ & $\begin{array}{l}\text { Atlas do Nordeste trará resultados melhores. } \\
\text { (Fontes, 2010: 233) }\end{array}$ \\
\hline $\begin{array}{l}\text { O Semiárido passa por escassez hídrica. } \\
\text { (Brasil, 2004: 9) }\end{array}$ & $\begin{array}{l}\text { Não foram consideradas as reservas hídricas } \\
\text { subterrâneas. (Feijó; Toggler, 2007) }\end{array}$ \\
\hline $\begin{array}{l}\text { Haverá mais água para a produção } \\
\text { da agricultura irrigada. (Nascimento; } \\
\text { Cagnin, 2010) }\end{array}$ & $\begin{array}{l}\text { O projeto é apresentado como se fosse } \\
\text { levar água e desenvolvimento para todo o } \\
\text { Semiárido. (Fontes, 2010) }\end{array}$ \\
\hline $\begin{array}{l}\text { O projeto é efetivo na redução das } \\
\text { desigualdades regionais e sociais. } \\
\text { (Nascimento; Cagnin, 2010) }\end{array}$ & $\begin{array}{l}\text { Como a água dos canais será protegida em } \\
\text { momentos de estiagem prolongada? } \\
\text { (Suassuna, 20o8: 45) }\end{array}$ \\
\hline
\end{tabular}

18 Em 2006, a Escola de Samba Estação Primeira de Mangueira desfilou no carnaval do Rio de Janeiro com o enredo "Das águas do Velho Chico nasce um rio de esperança". Segundo notícias da imprensa, a escola de samba carioca recebeu um patrocínio de 500 mil reais do governo cearense para promover o PTARSF. 


\begin{tabular}{|c|c|}
\hline $\begin{array}{l}\text { Criará empregos durante as obras. (Brasil, } \\
\text { 2004: 74) }\end{array}$ & Serão empregos temporários. (RIMA, 2004: 80) \\
\hline $\begin{array}{l}\text { Trará o desenvolvimento para o NE. (Brasil, } \\
\text { 2004: 10) }\end{array}$ & $\begin{array}{l}\text { É preciso pensar em um outro modelo } \\
\text { de desenvolvimento para o Nordeste. } \\
\text { (Costa, 2010) }\end{array}$ \\
\hline $\begin{array}{l}\text { Criará a sinergia hídrica entres os } \\
\text { mananciais nordestinos. (Brasil, 2004: 49) }\end{array}$ & $\begin{array}{l}\text { Concentrará ainda mais a água onde já está } \\
\text { armazenada. (Guimarães Jr. 2008: 29) }\end{array}$ \\
\hline $\begin{array}{l}\text { Levará água para } 12 \text { milhões de pessoas. } \\
\text { (Brasil, 2004:3) }\end{array}$ & $\begin{array}{l}\text { A sociedade continuará arcando com as } \\
\text { despesas das secas (Feijó; Toggler, 2007: 137) }\end{array}$ \\
\hline $\begin{array}{l}\text { O valor da obra está compatível com obras } \\
\text { similares em outros países. (Nascimento; } \\
\text { Cagnin, 2010: 89) }\end{array}$ & $\begin{array}{l}\text { Não há garantia de que apenas } 26 \mathrm{~m}^{3} \text { das } \\
\text { águas do São Francisco serão transpostas } \\
\text { quando a estrutura dos canais comporta } 127 \\
\mathrm{~m}^{3} \text {. (Lisboa, 2008: 23) }\end{array}$ \\
\hline $\begin{array}{l}\text { O governo está revitalizando o rio. } \\
\text { (Ministério da Integração Nacional, 2018) }\end{array}$ & $\begin{array}{l}\text { A revitalização prometida pelo governo } \\
\text { foi apenas uma estratégia para diminuir a } \\
\text { oposição à transposição. (Siqueira; Zellhuber, } \\
\text { 2007) }\end{array}$ \\
\hline $\begin{array}{l}\text { A produção de energia elétrica não será } \\
\text { prejudicada. (Brasil, 2004: 16) }\end{array}$ & $\begin{array}{l}\text { A retirada de água poderá interferir na } \\
\text { produção de energia elétrica que é consumida } \\
\text { em 95\% do NE. (Suassuna, 2007: 43) }\end{array}$ \\
\hline $\begin{array}{l}\text { As propostas de convivência com o semiárido, } \\
\text { a exemplo das cisternas de placas, são } \\
\text { importantes, mas não contemplam todas } \\
\text { as necessidades de desenvolvimento do NE. } \\
\text { (Brasil, 2004: 35) }\end{array}$ & $\begin{array}{l}\text { As propostas de convivência com o } \\
\text { Semiárido são eficazes. (Malvezzi, 2008) }\end{array}$ \\
\hline $\begin{array}{l}\text { A cobrança pela água beneficiará a } \\
\text { recuperação da bacia hidrográfica. (Kelman, } \\
\text { 2010: 268) }\end{array}$ & $\begin{array}{l}\text { Inaugura a guerra pela água no Brasil } \\
\text { (Guimarães Jr., 2008: 91) }\end{array}$ \\
\hline $\begin{array}{l}\text { A análise econômica demonstrou sua } \\
\text { viabilidade. (Nascimento; Cagnin, 2010) }\end{array}$ & $\begin{array}{l}\text { O custo da água será caro para os padrões do } \\
\text { país. (Feijó; Toggler, 2007) }\end{array}$ \\
\hline $\begin{array}{l}\text { As águas do Rio São Francisco pertencem à } \\
\text { União. (Nascimento; Cagnin, 2010) }\end{array}$ & $\begin{array}{l}\text { A favor da retirada de água da bacia para } \\
\text { a dessedentação de humanos e animais. } \\
\text { (Lisboa, 2008: } 23\end{array}$ \\
\hline $\begin{array}{l}\text { A outorga da Agência Nacional de Águas } \\
\text { considerou o pagamento pela água. } \\
\text { (Nascimento; Cagnin, 2010) }\end{array}$ & $\begin{array}{l}\text { O subsídio cruzado financiará o projeto. } \\
\text { (Suassuna, 2007: 46) }\end{array}$ \\
\hline $\begin{array}{l}\text { Os impactos nas áreas de construção dos } \\
\text { canais, se respeitado o paradigma do } \\
\text { desenvolvimento sustentável eliminará a } \\
\text { pressão sobre o meio ambiente. (Sarmento, } \\
\text { 2005: 84) }\end{array}$ & $\begin{array}{l}\text { Trará impactos ambientais para a área de } \\
\text { abrangência dos canais. (Suassuna, 2008: 45) }\end{array}$ \\
\hline $\begin{array}{l}\text { Os impactos serão minizados pelos } \\
\text { programas governamentais. (Brasil, 2004: } \\
\text { 95-113) }\end{array}$ & $\begin{array}{l}\text { Deficiências no Estudo de Impacto } \\
\text { Ambiental. (Matos, 2008) }\end{array}$ \\
\hline
\end{tabular}




\begin{tabular}{|c|c|}
\hline $\begin{array}{l}\text { O governo criou vários programas para } \\
\text { mitigar todos os impactos na biodiversidade. } \\
\text { (Brasil, 2004: 95-113) }\end{array}$ & $\begin{array}{l}\text { O estudo sobre a biodiversidade da área } \\
\text { abrangida tem várias lacunas. Os canais } \\
\text { trarão mudanças na biodiversidade local. } \\
\text { Espécies da ictiofauna da bacia doadora } \\
\text { poderão comprometer a biodiversidade da } \\
\text { região receptora. Assim como espécies da } \\
\text { fauna silvestre poderão sofrer com as obras. } \\
\text { (Barbosa; Lima Filho, 2010) }\end{array}$ \\
\hline $\begin{array}{l}\text { O governo vai assentar famílias ao longo do } \\
\text { canal. (Brasil, 2004: 108) }\end{array}$ & $\begin{array}{l}\text { A informação de que o governo pretende } \\
\text { assentar famílias ao longo do canal necessita } \\
\text { de estudos sobre a aptidão dos solos. } \\
\text { (Suassuna, 2010: 237) }\end{array}$ \\
\hline $\begin{array}{l}\text { O PTARSF promoverá o desenvolvimento } \\
\text { em uma região marcada pela desigualdade } \\
\text { socioeconômica. (Brasil, 2004) }\end{array}$ & $\begin{array}{l}\text { O PTARSF reproduz a lógica das grandes } \\
\text { obras nos estados do Nordeste. (Alves, 2010) }\end{array}$ \\
\hline $\begin{array}{l}\text { O PTARSF ajudará a manter as populações } \\
\text { no campo. (Brasil, 2004: 83) }\end{array}$ & $\begin{array}{l}\text { O PTARSF poderá promover a especulação } \\
\text { imobiliária. (Feijó; Toggler, 2007: 148) }\end{array}$ \\
\hline $\begin{array}{l}\text { O PTARSF é baseado em histórias de sucesso } \\
\text { em outros países, como Estados Unidos, por } \\
\text { exemplo. (Brasil, 2004: 26) }\end{array}$ & $\begin{array}{l}\text { A transposição do Rio Colorado impede } \\
\text { que a água chegue a sua foz, no México, } \\
\text { prejudicando milhares de mexicanos e o } \\
\text { meio ambiente. (Malvezzi, 2008: 9) }\end{array}$ \\
\hline $\begin{array}{l}\text { A água transposta reporá, nos açudes, a água } \\
\text { evaporada. (Brasil, 2004: 49) }\end{array}$ & $\begin{array}{l}\text { A água dos canais sofrerá uma grande perda } \\
\text { por evaporação, vazamento, infiltração. } \\
\text { (Feijó; Toggler, 2007: 130) }\end{array}$ \\
\hline $\begin{array}{l}\text { As bacias receptoras já possuem } \\
\text { infraestrutura pronta. (Rima, 2004: 34) }\end{array}$ & $\begin{array}{l}\text { A água terá que ser bombeada a até mais de } \\
300 \text { metros em algumas áreas. (Feijó; Toggler, } \\
\text { 2007: 126) }\end{array}$ \\
\hline $\begin{array}{l}\text { A PTARSF diminuirá os gastos com as } \\
\text { consequências das estiagens prolongadas. } \\
\text { (Brasil, 2004: 82) }\end{array}$ & $\begin{array}{l}\text { O PTARSF já custou mais de } 10 \text { bilhões de } \\
\text { reais, mais do que o dobro o orçamento } \\
\text { inicial. Alguns estudiosos do tema creem } \\
\text { que ela pode vir a custar } 20 \text { bilhões de reais. } \\
\text { (Silva, 2017: 102) }\end{array}$ \\
\hline $\begin{array}{l}\text { Evitará conflitos futuros por água no } \\
\text { Nordeste Setentrional. (Brasil, 2004) }\end{array}$ & $\begin{array}{l}\text { Criará novos conflitos pela água do São } \\
\text { Francisco. (Guimarães Jr., 2007: 109) }\end{array}$ \\
\hline $\begin{array}{l}\text { Garantia para os investidores privados. } \\
\text { (Nascimento; Cagnin, 2010) }\end{array}$ & $\begin{array}{l}\text { O PTARSF teve a sua primeira etapa } \\
\text { inaugurada pelo Presidente Temer em março } \\
\text { de 2017. O Eixo Norte ainda está em obras. } \\
\text { (Silva, 2017: 102) }\end{array}$ \\
\hline $\begin{array}{l}\text { Obras de travessia serão construídas para a } \\
\text { mobilidade do homem e da fauna. (Sarmento, } \\
2005: 83 \text { ) }\end{array}$ & $\begin{array}{l}\text { O Estudo de Impacto Ambiental não faz } \\
\text { relação entre as comunidades impactadas } \\
\text { e o uso que fazem do patrimônio cultural. } \\
\text { (Tomáz, 2010: 18) }\end{array}$ \\
\hline $\begin{array}{l}\text { O governo criou programas para atender a } \\
\text { todas as comunidades afetadas. (Brasil, 2004: } \\
99-113 \text { ) }\end{array}$ & $\begin{array}{l}\text { Atingirá várias comunidades indígenas e } \\
\text { quilombolas que ainda não tiveram os seus } \\
\text { territórios demarcados. (Tomáz, 2010) }\end{array}$ \\
\hline
\end{tabular}




\begin{tabular}{|l|l|}
\hline Garantirá a oferta hídrica. (Brasil, 2004: 74) & $\begin{array}{l}\text { É um dos semiáridos mais chuvosos do } \\
\text { mundo (Guimarães Jr., 2008D: 97). }\end{array}$ \\
\hline $\begin{array}{l}\text { A outorga da água para o projeto foi } \\
\text { autorizada pela Agência Nacional de Águas. } \\
\text { (Nascimento; Cagnin, 2010) }\end{array}$ & $\begin{array}{l}\text { O Conselho Nacional de Recursos Hídricos } \\
\text { ignorou as decisões do Comitê de Bacia do } \\
\text { Rio São Francisco. (Koury, 2008: 168) }\end{array}$ \\
\hline $\begin{array}{l}\text { A área dos canais tem baixa densidade } \\
\text { demográfica. (Sarmento, 2005: 84) }\end{array}$ & $\begin{array}{l}\text { Oficialmente, mais de 848 famílias serão } \\
\text { atingidas. (Ministério da Integração } \\
\text { Nacional, 2018) }\end{array}$ \\
\hline $\begin{array}{l}\text { O PTARS é uma obra para o benefício } \\
\text { nacional. (Sarmento, 2005: 8) }\end{array}$ & $\begin{array}{l}\text { A obra trará benefícios para as empreiteiras, } \\
\text { empresas de fruticultura e camarão. } \\
\text { (Malvezzi, 2008: 10) }\end{array}$ \\
\hline $\begin{array}{l}\text { Os custos com as secas são muito altos para o o } \\
\text { país (Sarmento, 2005) }\end{array}$ & $\begin{array}{l}\text { Está previsto que 85\% da receita do projeto } \\
\text { deverão ser gerados pelos consumidores de } \\
\text { ágituados no meio urbano das grandes } \\
\text { cidades da região nordeste (Guimarães Jr., } \\
\text { 20o8D: 101) }\end{array}$ \\
\hline $\begin{array}{l}\text { Diminuirá a migração para os centros } \\
\text { urbanos. (Brasil, 2004) }\end{array}$ & $\begin{array}{l}\text { Não há garantia de que os pequenos e } \\
\text { médios proprietários terão acesso à água. } \\
\text { (Feijó; Toggler, 2007) }\end{array}$ \\
\hline
\end{tabular}

\section{Os atingidos e atingidas pelo PTARSF}

Os conflitos que surgem motivados pela realização de megaprojetos são uma realidade não somente no Brasil, mas em todo o planeta. O deslocamento de grupos humanos como resultado da construção de grandes obras trará quase sempre resultados negativos aos grupos removidos de seus territórios, tanto pela desterritorialização física quanto pela perda de identidade cultural desenvolvida no meio onde viveram por gerações. Para Zhouri e Oliveira (2010: 457), "Na perspectiva dos chamados 'atingidos' pelos projetos de desenvolvimento, o lugar é referência para a construção de suas identidades políticas, ele significa, sobretudo, a retomada do controle de seu próprio destino." Ser realocado forçosamente é ser desempoderado.

Conflitos podem ser inevitáveis no campo dos recursos hídricos, ${ }^{19}$ especialmente quando o mercado vê a possibilidades de grandes lucros relacionados a esta riqueza natural. Com o incentivo para o agronegócio em várias regiões do Brasil nas últimas décadas, o uso intensivo da água na agricultura por meio da irrigação de grandes áreas vem gerando vários impactos nas comunidades ribeirinhas.

19 'A palavra 'rival' (ou 'rivalidade') vem do latim rivus (corrente ou riacho); um rival, portanto, é alguém que da margem oposta, usa a mesma fonte de água - daí a ideia de perigo ou ataque." (Petrella, 2002: 60). O PTARSF acabou tornando rivais os estados nordestinos doadores e os estados receptores das águas do Rio São Francisco. 
No caso do Rio São Francisco, já são inúmeros os conflitos com empresas e governo, "[...] que muitas vezes se alia aos segmentos do capital contra as territorialidades dos outros grupos existentes no interior da nação, tais como povos indígenas, os quilombolas e outros povos tradicionais." (Zhouri; Laschefski, 2010: 24). De um lado, as comunidades locais e do outro o governo. Em disputa, a questão do direito ao uso de suas terras e águas. Para Petrella (2002: 63),

Quando um conflito assume proporções importantes ou críticas, demonstra que a política regional ou nacional não foi capaz de desenvolver e implementar uma política hídrica integrada, inspirada na supremacia do interesse de todos com relação a um produto ou bem comum (res publica) e cujo objetivo fosse estimular a solidariedade entre todos os membros de uma comunidade regional ou nacional.

Não existem grandes obras sem atingidos. Muitos ou poucos, assistidos ou não, eles existirão. No último século, foram milhões as vítimas das construções de grandes barragens, por exemplo. É necessário ressaltar que o conceito de atingido por obras governamentais é muito recente no Brasil, ${ }^{20}$ assim como o seu reconhecimento. No caso do PTARSF, várias comunidades já foram atingidas pela construção dos canais e outras tantas ainda o serão.

São mais de oitocentas famílias oficialmente atingidas, segundo o Ministério da Integração Nacional, e que já foram ou serão realocadas pelo PTARSF para 18 Vilas de Produtivas Rurais - VPRs - em vários trechos da obra. No entanto, deve atentar-se para o fato de que estes são os números oficiais e iniciais, o que pode escamotear a situação de muitas famílias atingidas pela obra no futuro. O Estudo de Impacto Ambiental - EIA - foi realizado tendo como foco a área de construção do canal e não a bacia hidrográfica do Velho Chico, o que poderá aumentar o número de atingidos de forma expressiva.

O PTARSF criou o primeiro grupo de pessoas atingidas pela construção de canais de forma oficial no Brasil, ${ }^{21}$ sabendo-se que muitos atingidos não serão reconhecidos pelo governo brasileiro. Por causa do projeto, serão impactados

20 Em 26 de outubro de 2010, foi instituída a Lei n. 7.342, que trata dos atingidos pela construção de hidrelétricas, uma antiga reivindicação do Movimento dos Atingidos por Barragens - MAB. No entanto, o marco legal para atingidos por outras grandes obras, como canais, ainda inexiste. Para uma versão cinematográfica ficcional sobre atingidos por grandes obras no Brasil, ver Narradores de Javé (Caffé, 2003). Há outros casos de atingidos por construção de canais no Brasil, mas esta é a primeira vez que os atingidos se organizaram como grupo. Em junho de 2010, aconteceu, na cidade de Campina Grande, o I Encontro dos Atingidos e Atingidas pela Transposição do Rio São Francisco. Este foi o primeiro encontro deste tipo que se tem notícia no país. 
de forma negativa vários povos indígenas, comunidades tradicionais, ${ }^{22}$ grupos de remanescentes quilombolas, pescadores artesanais, vazanteiros e pequenos agricultores rurais em várias áreas do semiárido. Tais impactos negativos só confirmam que as grandes obras voltadas para o agro e o hidronegócio, embora sejam justificadas como possíveis salvadoras de problemas seculares e vendidas como propulsoras das melhoras socioeconômicas, nada mais são do que projetos para atender aos interesses de alguns grupos econômicos.

Um exemplo é o dos moradores da zona rural do município paraibano de São José de Piranhas. ${ }^{23}$ Naquela área, foram deslocadas mais de duzentas famílias que serão reassentadas em agrovilas construídas pelo governo. Depois de terem as suas propriedades expropriadas e serem indenizadas, estas famílias passaram a receber uma quantia monetária para pagar o aluguel de uma casa enquanto esperam a construção das agrovilas, fato que vem se arrastando por anos. Estas famílias, em especial as novas gerações, já se encontram em processo de perda de sua identidade rural, pois conforme Zhouri e Laschefski (2010: 25):

O deslocamento ou remoção desses grupos significa, não apenas a perda da terra, mas uma verdadeira desterritorialização, pois muitas vezes a nova localização, com condições físicas diferentes, não permite a retomada do modo de vida nos locais de origem, sem contar o desmoronamento da memória e da identidade centradas nos lugares. Assim, as comunidades perdem literalmente a base material e simbólica dos seus modos de socialização com a sua desestruturação.

No caso dos povos indígenas da região do Velho Chico, a exemplo de muitos outros povos originários e tradicionais que vivem o dilema da chegada de um modelo de "desenvolvimento" conflitante com relação ao meio onde vivem, aqueles já sabem os resultados que os megaprojetos lhes reservam. Estes são vendidos como a inserção no mundo moderno por agentes governamentais embasados por grandes campanhas midiáticas abafadoras de qualquer grito opositor às grandes obras.

Com a demanda por novos territórios e por água para a irrigação, a região semiárida nordestina vem sendo tomada pelo agronegócio, dificultando ainda mais a demarcação das terras indígenas ou fazendo com que estas sejam

22 Vale ressaltar que apenas na microrregião de Petrolina existem "[...] 18 comunidades quilombolas reconhecidas e/ou em processo de reconhecimento, totalizando 1807 famílias." (Sauer, 2010: 7).

23 Para detalhes sobre o caso dos atingidos de São José de Piranhas, ver a dissertação de mestrado Desterritorialização de populações locais: uma análise dos conflitos do projeto de integração do Rio São Francisco no município de São José de Piranhas (Gonçalves, 2014). 
demarcadas com um território aquém do desejado pelos povos indígenas daquela área, com a finalidade de atender a sede dos grupos empresariais que já se instalaram ou que lá se instalarão com o PTARSF.

O ocaso sofrido por estes indígenas pode ser comprovado ao nos defrontarmos com o que aconteceu com aqueles que foram atingidos pelas barragens construídas no Rio São Francisco nas últimas décadas para a geração de energia elétrica. Por causa delas, muitos foram deslocados de seus habitats, e, em muitos casos, não foram recompensados satisfatoriamente pelas suas perdas, algumas de valor imensurável, já que representavam seus lugares sagrados e sua cultura. Os povos indígenas questionam a obra do PTARSF porque há muito eles sabem, por experiência vivida e sofrida com outras grandes obras, que muitas vezes serviram apenas como canal para a corrupção sem nunca chegarem à conclusão, o que lhes é reservado como recompensa. Os responsáveis pelas grandes obras não levam em conta os moradores que habitam as áreas impactadas por considerá-los como a expressão do atraso. Como reflete Alier (2007), esses megaprojetos sempre vêm acompanhados de bagagem negativa não revelada a princípio, mas que é carregada às escondidas e que será sentida posteriormente quando não for mais possível negá-la. É esta bagagem, carregada pelas grandes obras, que pode ser traduzida como consequência para a vida dos atingidos e atingidas pelo PTARSF. Mais que um conflito com esse megaprojeto, este é um confronto com o padrão de "desenvolvimento" que ele representa. Neste sentido, movimentos sociais, como o Movimento dos Trabalhadores Sem Terra - MST, Articulação do Semi-Árido Brasileiro - ASA, Movimentos dos Pequenos Agricultores - MPA, Rede Brasileira de Justiça Ambiental - RBJA, Movimentos dos Atingidos por Barragens - MAB, entre outros, lançaram o Manifesto do acampamento dos movimentos sociais em Cabrobó, por ocasião do protesto do Povo Truká contra o PTARSF, onde afirmam,

Transposição não é a solução - esta é a verdade que não quer calar! Queremos um programa verdadeiro de convivência com o Semi-Árido! Queremos um projeto de desenvolvimento regional que atenda às reais necessidades da população do Semi-Árido e do São Francisco e não de uma minoria de empresários nacionais e estrangeiros! Queremos a democratização do acesso à água, com acesso livre da população aos açudes e às adutoras! Queremos controle social sobre o uso da água dos açudes e reservatórios geridos com competência! (Manifesto do Acampamento dos Movimentos Sociais em Cabrobó: 81)

Segundo Said (2009: 29), "Na área de abrangência do projeto além dos 26 povos indígenas estão localizadas 156 comunidades quilombolas e centenas de comunidades ribeirinhas." Não apenas os povos indígenas da bacia do São 
Francisco serão atingidos. O Povo Anacé, do município de Pecém-CE, já atingido pelo complexo Industrial e Portuário do Pecém, também será impactado pelo PTARSF, pois há uma ameaça de desapropriação de áreas do seu território por parte do governo cearense para a instalação de indústrias que terão a segurança hídrica supostamente garantida com as águas transpostas pelo PTARSF.

Os povos indígenas atingidos pelo PTARSF resistem ao seu avanço não por uma visão romântica sobre a natureza, mas por serem vítimas, há décadas, de projetos que prometem uma redenção socioeconômica que nunca chega e somente trazem a condenação destes povos ao seu extermínio, uma vez que são expulsos de suas próprias terras e presenciam a morte de seus bens naturais e culturais. Não serão apenas os povos indígenas a serem atingidos, porém, estes estão aqui destacados porque alguns deles já foram atingidos algumas décadas atrás com a construção de hidrelétricas no Velho Chico.

A divulgação do Relatório de Denúncia Povos Indígenas do Nordeste Impactados com a Transposição do rio São Francisco (Tomáz et al., 2010), revelou que o rio tem uma demanda por água maior do que ele pode suprir. Se já são inúmeros os projetos de irrigação a explorar as águas do Velho Chico, o governo vem anunciando incentivos para que grandes empresas comecem a se instalar no Semiárido para aproveitar a chegada das águas a serem transpostas pelo PTARSF. Este relatório (Tomáz et al., 2010: 20) também revela que:

Mais diretamente, a construção dos canais e do sistema de bombeamento de transposição passará pelos territórios do povo Truká, Tumbalalá e Pipipã (Eixo Norte e Leste) e pelos danos que provocará na vazão de água do rio afetará não menos diretamente os povos indígenas ribeirinhos como o Tuxá, Xucuru-Kariri, Xoxó, Kariri-Xocó e outros próximos à margem (Pankararé, Pankararu, Kalangó, Geripankó, Kaxangó, Kalancó, Akonã, dentre outros). No eixo Norte, interligando-se ao Complexo Portuário de Pecém, atinge o povo Anacé, no Ceará. A barragem de Pedra Branca implicará na inundação de parte do território do Povo Truká e Tumbalalá, divisa de Bahia e Pernambuco. Mais abaixo do rio, em nível mais embrionário de estudo de viabilidade, tem-se a previsão de construção da barragem de Pão de Açucar que afetará a vida sobretudo dos Povos Indígenas do Baixo São Francisco, como Xocó e Kariri-Xocó.

É notório que grande parte dos Estudos de Impactos Ambientais no Brasil não leva em conta as questões culturais dos povos atingidos. Assim, não foi diferente com o EIA para o PTARSF. O mesmo Relatório Denúncia (Tomáz et al., 2010: 18) afirma que o Rima divulgado sobre o PTARSF, no que concerne a 
este quesito, "[...] não apresenta sequer uma linha sobre as relações entre as comunidades afetadas pela obra e a utilização que fazem do patrimônio cultural, arqueológico e histórico ou ecológico da região." O que não é um caso isolado no país, obviamente. Como estabelecer uma valoração monetária para os vínculos dos que habitam os lugares que são transformados por grandes projetos, como o PTARSF? Qual a real dimensão dos impactos do PTARSF, já que eles são apresentados sempre como compensáveis financeiramente e mitigáveis em seus prejuízos? Marques (2006: 161-162) questiona:

Como avaliar os impactos socioambientais no campo simbólico quando o pragmatismo e racionalidade das nações consumistas e desenvolvimentistas ignoram, absolutamente, a dimensão espiritual/afetiva dos cálculos, das trocas, das recompensas financeiras. Como quantificar e negociar algo dessa dimensão?

A sociedade brasileira ainda não sabe o número exato dos que serão atingidos, suas características socioeconômicas, os prejuízos de ordem cultural com os deslocamentos destes grupos e, principalmente, o que lhes será dado por compensação pela perda de seus territórios. A julgar pelo que aconteceu com os muitos atingidos pelas barragens no curso do Rio São Francisco, eles não devem ter muita esperança de receber uma recompensa justa, ao menos economicamente.

\section{Considerações finais}

O discurso da escassez hídrica no semiárido é uma das justificativas para a realização de grandes projetos, como é o caso do PTARSF. A utilização desse argumento foi um dos focos para justificar o PTARSF, pois grupos favoráveis a este projeto dele se utilizavam para garantir que este projeto aliviaria de vez a insegurança hídrica de 12 milhões de pessoas. $\mathrm{O}$ apelo a uma possível falta de um bem essencial à vida ganhou vulto, pois é evidente que todos sabem da importância da água como elemento fundamental para a sobrevivência da vida no planeta. Mais uma vez, a distribuição da água em uma região na qual ela sempre foi moeda de troca política e econômica continua sendo utilizada como justificativa para grandes obras, como o PTARSF.

Parte da sociedade brasileira ainda tem uma visão de que a água levada pelos canais do PTARSF salvará os cidadãos de todos os seus problemas. É no tripé sede, fome e desenvolvimento que focam as peças de marketing do PTARSF. É óbvio que existem localidades que sofrem com a escassez hídrica, gerando insegurança na população, mas há outras soluções que podem ser mais eficazes para mitigar este problema no NE. 
Os novos embates trazem novas questões e novos desafios para os atingidos pelo PTARSF, pois já não se dão mais no campo local, mas transpassam as fronteiras geográficas onde eles habitam, e os desafiam para novos conhecimentos no campo ambiental, jurídico, político e econômico, fazendo com que estes grupos busquem novas estratégias que possibilitem sua permanência naquele lugar.

Há um discurso que insiste na realização do PTARSF, utilizando um argumento salvacionista, mesmo diante do fato de o Rio São Francisco, maior manancial da região NE, estar passando por um processo acentuado de degradação. Cientistas e ativistas anunciam e denunciam as causas de tal degradação como sendo as grandes barragens e a retirada de água de forma exagerada para a irrigação.

Mais uma vez, aqueles que foram e são marginalizados pelo poder público, o mesmo que deveria garantir-lhes uma sobrevivência digna, estão sendo vítimas da relação danosa entre o Estado e o capital com a intenção de desenvolver o agro e o hidronegócio na região do semiárido nordestino. As populações que lá habitam e que serão atingidos pelo PTARSF são vistas como um empecilho para o progresso pela tecnocracia moderna brasileira, pois, ao questionar tal projeto, levantam dúvidas sobre o sucesso prometido pelo governo com esta obra, revelando a realidade daquelas populações e de tantas outras atingidas pelo PTARSF.

\section{Referências}

AB’SABER, Aziz. A transposição das águas do São Francisco: análise crítica. Revista USP. São Paulo, n. 70, Jul-Ago 2006, pp. 6-13.

. A quem serve a transposição? In: MOREIRA, Gilvander Luís (Org.). Dom Cappio: rio e povo: Frei Luiz, um profeta na luta em defesa da vida do rio São Francisco e do seu povo. Transposição, não! São Leopoldo, CPT/CEBI. 2008, pp. 31-33. ALCÂNTARA, Lúcio. Um projeto para mudar o Brasil. Revista Estudos Avançados. São Paulo, Instituto de Estudos Avançados da USP, v. 20, n. 56, Jan-Abr 2006, pp. 293-299.

ALIER, Joan Martínez. O ecologismo dos pobres. São Paulo, Editora Contexto, 2007, $379 \mathrm{p}$.

ALVES FILHO, João. Toda a verdade sobre a transposição do Rio São Francisco. Rio de Janeiro. Mauad, 2008, $254 \mathrm{p}$.

ALVES, Gilson. Transposição do Rio São Francisco: elementos para reflexão. In: MENEZES, Ana Célia Silva; SILVA, Flávio José Rocha da. A resistência à transposição na Paraíba: histórias em defesa da terra, das águas e dos povos do Nordeste. João Pessoa, Sal da Terra, 2010, pp. 44-48. 
. Transposição de águas do rio são Francisco: um atentado aos interesses nacionais. In: QUINTIERE, Marcelo de Miranda Ribeiro (Org.). Transposição do São Francisco: uma análise dos aspectos positivos e negativos do projeto que pretende transformar a região Nordeste. Curitiba, Juruá Editora, 2010, pp. 103-181.

AZEVEDO, Maria Regina da Silva. A representação popular na Câmara dos Deputados e o pacto federativo no Brasil: estudo de caso - transposição do Rio São Francisco. In: Biblioteca Digital da Câmara dos Deputados, 2008, pp. 49-66.

AZEVEDO, Luiz Gabriel Todt de. Integração de bacias hidrográficas. In: Centro de Estudos Estratégicos; Agência Nacional de Águas. A questão da água no Nordeste. Brasília, CGEE, 2012, pp. 331-372.

BARBOSA, José Ethan de Lucena Barbosa; LIMA FILHO, Gilberto Queiroz de. Potenciais impactos ambientais da transposição do rio São Francisco no estado da Paraíba. In: MENESES, Ana Célia Silva; ROCHA, Flávio. A resistência à transposição do Rio São Francisco na Paraíba: histórias de luta em defesa da terra, das águas e dos povos do Nordeste. João Pessoa, Sal da Terra, 2010, pp. 49-53.

BARLOW, Maude. El convenio azul: la crisis global de agua y la batalla futura por el direcho al agua. Santiago: Programa Chile sustentable/Concil of Canadians, 2008. BEZERRA, Evandro. O Rio São Francisco: a polêmica da transposição. Fortaleza: Seri\&a Gráfica, 2002.

BRASIL. Canal São Francisco-Jaguaribe. Rio de Janeiro, DNOCS, 1959.

Projeto semi-árido: proposta de desenvolvimento sustentável da bacia do Rio São Francisco e do semi-árido nordestino. Brasília, CODEVASF, 1996.

. Relatório de Impacto Ambiental do Projeto de Integração do Rio São Francisco com bacias hidrográficas do Nordeste Setentrional - Rima. Brasília, Ministério da Integração Nacional, 2004.

CASTRO, Cesar Nunes. Impactos do projeto de transposição do Rio São Francisco na agricultura irrigada no Nordeste Setentrional. Instituto de Pesquisa Econômica Aplicada, Rio de Janeiro, 2011, pp. 7-34.

COELHO, Marco Antônio Tavares. Os descaminhos do São Francisco. São Paulo, Paz e Terra, 2005, $272 \mathrm{p}$.

COSTA, José Jonas Duarte da. Sobre a transposição do Rio São Francisco. In: MENEZES, Ana Célia Silva; SILVA, Flávio José Rocha da. A resistência à transposição na Paraíba: histórias em defesa da terra, das águas e dos povos do Nordeste. João Pessoa, Sal da Terra, 2010, pp. 35-44.

ESCOBAR, Arturo. Contra el (neo)desarrollismo. In: Impasse: dilemas politicos del presente. Buenos Aires, Coletivo Situaciones, 2009, $192 \mathrm{p}$.

FARIAS, José Alexandre Moreira et al. Sinergia hídrica em sistemas integrados de reservatórios: estudos de casos relacionados com a transposição das águas do Rio São Francisco. In: XVI Simpósio Brasileiro de Recursos Hídricos, João Pessoa, 2005. 
FARIAS, José Roberto Machado; ALMEIDA, Marcelo Eugenio Feitosa. A transposição do rio São Francisco: política pública e consequências jurídicas para a concretização do direito fundamental à água. In: QUINTIERE, Marcelo de Miranda Ribeiro (Org.). Transposição do São Francisco: uma análise dos aspectos positivos e negativos do projeto que pretende transformar a região Nordeste. Curitiba, Juruá Editora, 2010, pp. 185-195.

FEIJÓ, Ricardo; TORGGLER, Sérgio. Alternativas mais eficientes para a transposição do rio São Francisco. Caderno CEAS, n. 227, Salvador, Loyola, Julho-Setembro 2007, pp. $125-150$.

FONTES, Luiz Carlos da Silveira. Transposição: anatomia de uma fraude hídrica e do conflito de usos das águas do Rio São Francisco. In: QUINTIERE, Marcelo de Miranda Ribeiro (Org.). Transposição do São Francisco: uma análise dos aspectos positivos e negativos do projeto que pretende transformar a região Nordeste. Curitiba, Juruá Editora, 2010, pp. 221-260.

GONÇALVES, Cláudio Dias Barbosa. Desterritorialização de Populações Locais: Uma análise dos conflitos do projeto de integração do Rio São Francisco no município de São José de Piranhas. Dissertação de Mestrado, Desenvolvimento Regional, UEPB, 2014. GONÇALVES, Claudio Ubiratan; OLIVEIRA, Cristiane Fernandes. Rio São Francisco: as águas correm para o mercado. Boletim Goiano de Geografia, v. 29, n. 2, jul-dez 2009, pp. 113-125.

GUIMARÃES JR., João Abner. Reforma hídrica no Nordeste como alternativa à transposição do rio são Francisco. Carderno CEAS, n. 227, Julho-Setembro 2007, pp. 107-118.

. Entrevista com João Abner Junior sobre a transposição das águas. In: MOREIRA, Gilvander Luís (Org.). Dom Cappio: rio e povo: Frei Luiz, um profeta na luta em defesa da vida do rio São Francisco e do seu povo. Transposição, não! São Leopoldo, CPT/CEBI. 2008A, pp. 56-70.

Rio São Francisco: "O movimento contra o projeto precisa ser politicamente ampliado e nacionalizado (entrevista). In: Cadernos IHU em formação. São Leopoldo, Unisinos, ano 4, n. 28, 2008B, pp. 27-29.

Transposição do rio São Francisco não é a solução: uma reforma hídrica no Nordeste como alternativa. In: MOREIRA, Gilvander Luís (Org.). Dom Cappio: rio e povo: Frei Luiz, um profeta na luta em defesa da vida do rio São Francisco e do seu povo. Transposição, não! São Leopoldo, CPT/CEBI, 2008C, pp. 71- 79.

. O presente de grego da transposição do Rio São Francisco. In: ALVES FILHO, João. Toda a verdade sobre a transposição do Rio São Francisco. Rio de Janeiro, Mauad X, 2008, p. 91. 
. O destino dos canais da transposição do rio São Francisco. In: ZINCLAR, João. O Rio São Francisco e as águas no sertão. Campinas, Silvamarts, 2010.

KELMAN, Jerson. Transposição: a preocupação com a sustentabilidade. In: QUINTIERE, Marcelo De Miranda Ribeiro (Org.). Transposição do São Francisco: uma análise dos aspectos positivos e negativos do projeto que pretende transformar a região Nordeste. Curitiba, Juruá Editora, 2010, pp. 261-274.

KHOURY, Luciana Espinheira da Costa. Aspectos jurídicos do projeto de Transposição do rio São Francisco e a atuação do Ministéiro Público brasileiro. Carderno CEAS, n. 227, Julho-Setembro 2007, pp. 85-92.

KHOURY, Luciana Espinheira da Costa; MARQUES, Daisy dos Santos. Ilegalidades do projeto de transposição do Rio São Francisco e afronta ao Estado Democrático de Direito. In: MOREIRA, Gilvander Luís (Org.). Dom Cappio: rio e povo: Frei Luiz, um profeta na luta em defesa da vida do rio São Francisco e do seu povo. Transposição, não! São Leopoldo, CPT/CEBI, 2008, pp. 206-213.

KHOURY, Jorge. Contexto para uma transposição. In: ALVES FILHO, João. Toda a verdade sobre a transposição do Rio São Francisco. Rio de Janeiro, Mauad X, 2008, pp. 161-170.

LANNA, Antônio Eduardo Leão. Hidroeconomia. In: REBOUÇAS, Aldo Da Cunha; BRAGA, Benedito; TUNDISI, José Galízia. (Orgs.) Águas doces no Brasil: capital ecológico, uso e conservação. São Paulo, Escrituras Editora, 2002, pp. 531-562.

LISBOA, Heringer Apolo. Transposição do Rio São Francisco: das contradições às soluções (entrevista). In: Cadernos IHU em formação. São Leopoldo, Unisinos, ano 4, n. 28, 2008, pp. 22-26.

LOUREIRO, Maria Rita; TEIXEIRA, Marco Antônio Carvalho, FERREIRA, Alberto Mello. Desenvolvendo capacidades estatais: conflitos e interesses no Projeto de Integração do Rio São Francisco. Desenvolvimento em questão. Ijuí, Editora Unijuí, ano 12, n. 28. Out-Dez., 2014, pp. 5-36.

MALVEZZI, Roberto. Semi-Árido - uma visão holística. Brasília, Pensar Brasil, 2001. A vida pela vida. A transposição do Rio São Francisco em debate (entrevista). In: Cadernos IHU em formação. São Lopoldo: Unisinos, ano 4, n. 28, 2008, pp. 8-16. . Discurso ambiental brasileiro e investimentos do PAC e BNDES. Simpósio internacional sobre mudanças climáticas. Brasília. 2009. Disponível em: <http://www. adital.com.br/site/noticia_imp.asp? cod=40097\&lang=PT>. Acesso em: 12 nov. 2018. MANIFESTO DO ACAMPAMENTO DOS MOVIMENTOS SOCIAIS EM CABROBÓ. In: Carderno CEAS, n. 227, Julho-Setembro 2007, pp. 81.

MARANHÃO, Ney; AYRIMORAES, Sérgio. Os usos da água e o desenvolvimento regional. In: CENTRO DE GESTÃO E ESTUDOS ESTRATÉGICOS; AGÊNCIA NACIONAL DE ÁGUAS. A questão da água no Nordeste. Brasília, CGEE, 2012, pp. 121-155. 
MARQUES, Juracy. Ecologias do São Francisco. Paulo Afonso, Fonte Viva, 2006.

MARTINS, Magno. O Nordeste que deu certo. Recife, Comunicarte, 1993, 289 p.

MARTINS, Rodrigo Constante. De bem comum a outro azul: a crença na gestão racional da água. Contemporânea: Revista de Sociologia da UFSCAR. São Carlos, v. 2, n. 2, jul-dez 2012, pp. 465-488.

MATOS, Eduardo Lima de. Aspectos jurídicos controvertidos no projeto de transposição. In: ALVES FILHO, João. Toda a verdade sobre a transposição do Rio São Francisco. Rio de Janeiro, Mauad X, 2008, pp. 142-160.

MENEZES, Ana Célia Silva; SILVA, Flávio José Rocha da. A resistência à transposição do Rio São Francisco na Paraíba: histórias em defesa da terra, das águas e dos povos do Nordeste. João Pessoa, Sal da Terra, 2010, 88 p.

MINISTÉRIO DA INTEGRAÇÃO NACIONAL. Projeto São Francisco. Disponível em: $<$ http://www.integracao.gov.br/web/projeto-sao-francisco)>. Acesso em: 04 nov. 2018. NASCIMENTO, Pedro Brito do; CAGNIN, João Urbano. A integração do Rio São Francisco no Nordeste. In: QUINTIERE, Marcelo De Miranda Ribeiro. (Org.). Transposição do São Francisco: uma análise dos aspectos positivos e negativos do projeto que pretende transformar a região Nordeste. Curitiba: Juruá Editora, 2010, pp. 65-101.

NETO, Leonardo Guimarães; SILVA, Marlene Maria da; GALINDO, Osmil. As áreas de influência direta do projeto. In: PESSOA, Dirceu; GALINDO, Osmil. Transposição do Rio São Francisco: a dimensão socioeconômica. Recife, Fundação Joaquim Nabuco, 1989.

NUNES, Carlos Motta. Projeto de integração do Rio São Francisco com bacias hidrográficas do Nordeste setentrional - PISF. In: MAGALHÃES, Antônio Rocha. A questão da Água no Nordeste. Brasília: Centro de Gestão E Estudos Estratégicos/ Agência Nacional de Águas, 2010, pp. 373-390.

PESSOA, Dirceu; GALINDO, Osmil (Orgs.). Transposição do Rio São Francisco: a dimensão socioeconômica. Recife, Fundaj-Massagana, 1989, 285 p.

PETRELLA, Ricardo. O manifesto da água. Rio de Janeiro, Vozes, 2002, 159 p.

QUINTIERE, Marcelo de Miranda Ribeiro (Org.). Transposição do São Francisco: uma análise dos aspectos positivos e negativos do projeto que pretende transformar a região Nordeste. Curitiba, Juruá Editora, 2010.

REBOUÇAS, Aldo. Água doce no mundo e no Brasil. In: REBOUÇAS, Aldo Da Cunha, BRAGA, Benedito; TUNDISI, José Galízia (Orgs.). Águas doces no Brasil: capital ecológico, uso e conservação. São Paulo, Escrituras Editora, 2002, pp. 1-37.

. Aspectos relevantes do problema da água. In: REBOUÇAS, Aldo Da Cunha, BRAGA, Benedito; TUNDISI, José Galízia (Orgs.). Águas doces no Brasil: capital ecológico, uso e conservação. São Paulo, Escrituras Editora, 2002, pp. 687-703. 
RIBEIRO, Manoel Bomfim Dias. Transposição: uma análise cartesiana. In: MOREIRA, Gilvander Luís (Org.). Dom Cappio: rio e povo: Frei Luiz, um profeta na luta em defesa da vida do rio São Francisco e do seu povo. Transposição, não! São Leopoldo, CPT/CEBI, 2008A.

Transposição: um projeto para reflexão. In: QUINTIERE, Marcelo de Miranda Ribeiro (Org.). Transposição do São Francisco: uma análise dos aspectos positivos e negativos do projeto que pretende transformar a região Nordeste. Curitiba, Juruá Editora, 2010, pp. 35-62.

RIBEIRO, Wagner Costa. Geografia política da água. São Paulo, Annablume, 2008, 162 p. SAID, Magnólia. Transposição do Rio São Francisco: a outra margem da história. Fortaleza, Editora Expressão Gráfica, 2009, 87 p.

SARMENTO, Francisco Jácome. Transposição do Rio São Francisco: realidade e obra a construir. Brasília, Do Autor, 2005, 131 p.

A integração do São Francisco: verdade e mito. Revista USP. São Paulo, n. 70, Julho-Agosto 2006, pp. 6-13.

SAUER, Sérgio. Relatório da missão à Petrolina e região do Rio São Francisco (PE): violações de Direitos Humanos de Comunidades Quilombolas, Povos Indígenas e famílias assentadas de reforma agrária às margens do rio São Francisco. Brasília-Recife, DHESCA Brasil, 2010.

SILVA, Flávio José Rocha da. O nascimento da resistência contra à transposição na Paraíba. In: MENEZES, Ana Célia Silva; SILVA, Flávio José Rocha da. A resistência à transposição na Paraíba: histórias em defesa da terra, das águas e dos povos do Nordeste. João Pessoa, Sal da Terra, 2010, pp. 14-24.

SILVA, Flávio José Rocha Da; ARRUDA, Rinaldo Sérgio Vieira. Povos indígenas e a luta em defesa do rio São Francisco. Revista Sustentabilidade em Debate. Brasília. V. 4, n. 2. jul/dez 2013. pp. 138-148. Disponível em: <http://periodicos.unb.br/index.php/ sust/article/view/8744>. Acesso em: 12 nov. 2018.

. Povos indígenas atingidos pelo Projeto de Transposição do Rio São Francisco. In: SILVA, Edson Hely; SANTOS, Carlos Alberto Batista; OLIVEIRA, Edvania Granja da Silva. História ambiental: recursos naturais e povos tradicionais no Semiárido nordestino. Curitiba, Appris, 2017, pp. 89-118.

SILVA, Roberto Marinho Alves da. Entre o combate à seca e a convivência com o SemiÁrido: transições paradigmáticas e sustentabilidade do desenvolvimento. Dissertação de Doutorado, Desenvolvimento Sustentável, Universidade de Brasília, 2006.

SIQUEIRA, Ruben. De Sobradinho à transposição: para onde corre o São Francisco. In: MOREIRA, Gilvander Luís (Org.). Dom Cappio: rio e povo: Frei Luiz, um profeta na luta em defesa da vida do rio São Francisco e do seu povo. Transposição, não! São Leopoldo, CPT/CEBI, 2008, pp. 191-202. 
SIQUEIRA, Ruben; ZELLHUBER, Andrea. Rio São Francisco em descaminho; degradação e revitalização. Cadernos CEAS. Salvador, Loyola, 2007, pp. 7-32.

SIQUEIRA, José Eduardo de Campos. Ideologia da água e privatização dos serviços de saneamento. In: DOWBOR, Ladislaw; TAGNIN, Renato Arnaldo (Orgs.). Administrando a água como se fosse importante: gestão ambiental e sustentabilidade. São Paulo, Senac Editora, 2005, pp. 37-46.

STOLF, Rubismar et al. Water transfer from São Francisco River to Semiarid Northeast of Brazil:

TECHNICAL data, environmental impacts, survey of opinion about the amount to be transfered. Revista de Eng. Agric. Jaboticabal, v. 32, n. 6. Nov/Dez. 2012, pp. 998-1010. Disponível em: <http://www.scielo.br/pdf/eagri/v32n6/o1.pdf>. Acesso em: 12 nov. 2018.

SUASSUNA, João. Contribuição ao estudo hidrológico do Semi-Árido nordestino. Recife, Massagana, 2000.

. As águas do Nordeste e o projeto de transposição do rio São Francisco. In: $\mathrm{Ca}$ derno CEAS. Salvador, 2007, pp. 35-48.

O governo quer impor garganta abaixo um projeto tecnicamente ruim, socialmente preocupante e politicamente desastroso (entrevista). In: Cadernos IHU em formação. São Leopoldo, Unisinos, 2008, pp. 43-45.

. Transposição do Rio São Francisco na perspectiva do Brasil Real. São Paulo, Porto de Ideias, 2010.

Hidrocoronelismo hídrico na transposição das águas do São Francisco. In: PELAZZO JR., José Truda; CARBOGIM, João Bosco Priamo. Conservação da natureza: e eu com isso? Fortaleza, Fundação Brasil Cidadão, 2012, pp. 104-127. Disponível em <http://www.globalgarbage.org/praia/downloads/Conservacao_da_ Natureza_e_Eu_Com_Isso.p df.> Acesso em: 12 nov. 2018.

TAVARES, Maria da Conceição; ANDRADE, Manuel Correia de; PEREIRA, Raimundo. Seca e poder: entrevista com Celso Furtado. São Paulo, Editora Fundação Perseu Abramo, 1998, $96 \mathrm{p}$.

TOMÁZ, Alzeni et al. Relatório Povos indígenas do Nordeste impactados com a transposição do Rio São Francisco. Paulo Afonso: APOIMNE, AATR, NECTAS/ UNEB, CPP, CIMI, 2010.

ZHOURI, Andréa; OLIVEIRA, Raquel. Quando o lugar resiste ao espaço: colonialidade e processo de territorialização. In: ZHOURI, Andréa; LASCHEFSKI, Klemens (Orgs). Desenvolvimento e conflitos ambientais. Belo Horizonte, Editora UFMG, 2010, pp. 439-462.

ZHOURI, Andréa; LASCHEFSKI, Klemens. Desenvolvimento e conflitos ambientais: um novo campo de investigação. In: ZHOURI, Andréa; LASCHEFSKI, Klemens. 
(Orgs). Desenvolvimento e conflitos ambientais. Belo Horizonte, Editora UFMG, 2010, pp. 11-31.

\section{Filmografia}

CAFFÉ, Eliane. Narradores de Javé, 2003.

CANCINO, Cristian. Ser Tão Progresso, 2012.

FRENTE CEARENSE POR UMA NOVA CULTURA DE ÁGUA; Transposição do Rio São

Francisco e águas no Ceará: os cursos da privatização, 2007.

Recebido em 12/12/2016

Aprovado em 19/02/2018

\section{Como citar este artigo:}

SILVA, Flávio José Rocha da. Grandes obras no nordeste: o caso do projeto de transposição das águas do rio São Francisco. Contemporânea - Revista de Sociologia da UFSCar, v. 8, n. 2, jul.- dez. 2018, pp. 607-634. 